\title{
APPLICATION OF RESPONSE SURFACE METHODOLOGY TO OPTIMIZE MICROWAVE-ASSISTED EXTRACTION OF TOTAL PHENOLIC COMPOUNDS FROM CAUCASIAN WHORTLEBERRY (Vaccinium arctostaphylos)
}

\author{
Naciye Kutlu*, Cansu Bicak, Duygu Ekinci, Ezgi Kilic, \\ Naz Erdem, Asli Isci, Ozge Sakiyan \\ Department of Food Engineering, Ankara University, Ankara, Turkey
}

Received / Geliş: 25.09.2017; Accepted / Kabul: 11.02.2018; Published online / Online bask1: 27.02.2018

Kutlu, N., Bicak, C., Ekinci, D., Kilic, E., Erdem, N., Isci, A., Sakiyan, Ö. (2018). Application of response surface methodology to optimize microwave-assisted extraction of total phenolic compounds from Caucasian whortleberry (Vacinium arctostaphylos). GIDA (2018) 43 (2): 264-272 doi: $10.15237 /$ gida.GD17087

\begin{abstract}
Microwave-assisted extraction (MAE) is commonly used in recent years as an innovative approach to enhancing the quality of extracts while decreasing the extraction time and the solvent consumption in comparison to conventional techniques. In this study, the influence of microwave power, solid concentration and extraction time on total phenolic content (TPC), colour values and dielectric properties of Caucasian whortleberry were investigated. The process variables were optimized using response surface methodology. The highest TPC from Caucasian whortleberry was obtained at an extraction time of $3.5 \mathrm{~min}$, a solid concentration of $15 \%$ and a microwave power of $360 \mathrm{~W}$. The results showed that $\mathrm{L}^{*}$ and $\mathrm{a}^{*}$ values of the extracts were highly correlated with TPC by a second-order polynomial. Moreover, no significant difference was found in dielectric properties between the groups.

Keywords: Caucasian whortleberry, microwave-assisted extraction, optimization, total phenolic content, dielectric.

\section{LIKAPADAN (Vaccinium arctostaphylos) TOPLAM FENOLIK BİLEŞİKLERİN MİKRODALGA DESTEKLİ EKSTRAKSIYYONUNUN YANIT YÜZEY YÖNTEMİ İLE OPTİMİZASYONU}

ÖZ

Mikrodalga-destekli ektraksiyon (MAE), konvansiyonel tekniklerle ile karşılaştıılddı̆ında ekstraksiyon süresi ile solvent tüketimini düşürürken, ekstrakt kalitesini arttırması nedeniyle yenilikçi bir yöntem olarak son yıllarda yaygın bir şekilde kullanılmaktadır. Bu çalışmada, mikrodalga gücü, katı konsantrasyonu ve ekstraksiyon süresinin, likapa meyvesinin toplam fenolik içeriği (TPC), renk değerleri ve dielektrik özellikleri üzerine etkisi incelenmiştir. Proses değişkenleri yanıt yüzey yöntemi kullanılarak optimize edilmiştir. Likapadan en yüksek TPC, $360 \mathrm{~W}$ mikrodalga gücü, \%15 kat1 konsantrasyonu ve 3.5 dakika ekstraksiyon süresi koşullarında elde edilmiştir. Sonuçlara bakıldığında, ekstrakların L* ve a* değerleri, TPC ile ikinci dereceden polinom ile yüksek korelasyon göstermiştir. Ayrıca, grupların dielektrik özellikleri arasında anlamlı fark bulunamamışır.

Anahtar kelimeler: Likapa, mikrodalga destekli ekstraksiyon, optimizasyon, toplam fenolik içerik, dielektrik.

${ }^{*}$ Corresponding author / Yazışmalardan sorumlu yazar;

$\triangle$ nkutlu@ankara.edu.tr,

(f) (+90) 312203 3300/3632

冝 (+90) 03123178711 


\section{INTRODUCTION}

Blueberry is a tree species native to the northern hemisphere and belongs to the genus Vaccinium and family Ericaceae. Caucasian whortleberry ( $V$. arctostaphylos), which is one of the wild blueberry species, is known as "Likapa" in Turkey and it is native to Western Asia (Iran and Turkey), the Caucasus (Armenia; Azerbaijan; Georgia; Russia), and Southeastern Europe (Bulgaria, Poland) (Jacquemart, 1996). It is naturally adapted on Black Sea region of Northern, particularly North-eastern Turkey. Caucasian whortleberry fruits have high antioxidant capacity and contain high levels of anthocyanin and other phenolic compounds such as phenolic acids, catechins and flavonols (Prior et al., 1998). They are also a good source of vitamin $\mathrm{C}, \mathrm{E}$ and carotenoids (Giovanelli and Buratti, 2009). Considering the valuable health benefits of the compounds present in Caucasian whortleberry, high value products can be developed from this fruit. Extracts of Caucasian whortleberry can be used in functional foods, nutraceuticals, and pharmaceutical applications.

Extraction is a process which is used to separate a substance from a matrix. It includes liquid-liquid and solid-liquid types. Generally, the most commonly used conventional methods are Soxhlet extraction, maceration, extraction by infusion, and vapour distillation (Kislik, 2012). Recently, instead of conventional methods, green processes such as microwave-assisted, ultrasound-assisted, enzymatic and pressurizedsolvent extractions have been investigated widely. These extraction systems can be used with nonhazardous solvents such as water and also provide solvent and energy recovery (Ivanovic et al., 2014; Boukroufa et al., 2015; Chen et al., 2015).

Microwave-assisted extraction (MAE) is commonly used in recent years as an innovative approach to enhancing the quality of extracts while decreasing the extraction time and the solvent consumption in comparison to conventional techniques (Karabegovic et al., 2014). During MAE, volumetric heating of microwave irradiation causes the disruption of cell structure and helps to separate the target compounds from the matrix. Efficient separation and rapid extraction are the most important advantages of MAE process (Dahmoune et al., 2015; Setyaningsih et al., 2015). A large number of MAE studies have been reported for the extraction of biological compounds including phenolic compounds from eucalyptus leaves (Gharekhani et al., 2012), broccoli (Jokic et al., 2012), grape seeds (Krishnaswamy et al., 2013), chokeberry (Simic et al., 2016), cabbage (Sookjitsumran et al., 2016), barberry (Ardestani et al., 2016). In addition, there are several articles which focus on the extraction of anthocyanins from blueberries (Zheng et al., 2013; Routray and Orsat, 2014; Routray et al., 2014; Zhou et al., 2015). However, the microwave-assisted extraction of phenolic compounds from Caucasian whortleberry is lacking in literature. Therefore, the main objective of the present work was to extract total phenolic compounds from Caucasian whortleberry by MAE. It was also aimed to optimize the process parameters for higher phenolic content by response surface analysis. Moreover, colour values and dielectric properties of the extracts were determined at different extraction conditions. In addition, simple mathematical models were proposed to predict TPC as a function of colour values.

\section{MATERIAL AND METHODS \\ Material}

Caucasian whortleberry samples used in the study were obtained from a local producer (Hopa Yaban Mersini) in Artvin (a province of northeast Turkey, on the eastern Black Sea region). They were cleaned and blended for 10 seconds. The moisture contents of the samples were analysed by infrared moisture analyzer (MA150, Sartorius, Germany). Initial moisture content of the sample was $84 \pm 1 \%$ (wet basis).

All the chemicals were analytical grade. Sodium carbonate and Gallic acid were obtained from Sigma Aldrich (USA). Folin-Ciocalteu reagent and ethanol were obtained from Merck (Germany).

\section{Microwave-assisted extraction}

Extractions were performed in a domestic microwave oven (GMOM 25, General Electric, 
USA) which was modified in order to condense the vapour generated during extraction (Fig. 1). Different amount of samples were mixed with water and placed into the extraction flask that had the capacity of $500 \mathrm{ml}$. Microwave power (270, 360 and $450 \mathrm{~W})$, extraction time $(2.5,3.0$ and 3.5 min) and solid concentration (5\%,10\% and $15 \%)$ were the independent variables used in MAE. After the extraction process, the extracts were filtered through filter paper and stored at $-18^{\circ} \mathrm{C}$ until further use. All of the experiments were performed in duplicates.

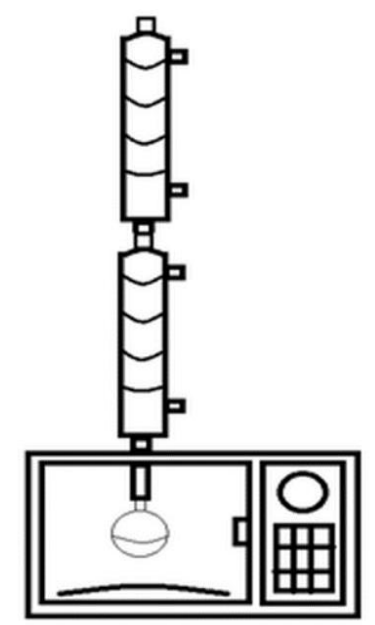

Fig. 1. Schematic diagram of microwave-assisted extraction

\section{Maceration}

The samples were extracted at optimum solid concentration $(13.9 \%)$ for $24 \mathrm{~h}$ at room temperature. The optimum solid concentration were decided according to TPC, $\mathrm{L}^{*}$ and $\mathrm{b}^{*}$ values of microwave assisted extracts of Caucasian whortleberry samples. Response surface methodology was used for optimization. The tool took max TPC and min $\mathrm{L}^{*}$ and $\mathrm{b}^{*}$ values into consideration for optimum point determination. Water bath (SBD-313, Simsek, Turkey) was used to maceration and samples were agitated at regular intervals. The extracts were then filtered through a filter paper and stored at $-18^{\circ} \mathrm{C}$ until further use (Xu et al., 2016).

\section{Determination of total phenolic content}

The total phenolic content (TPC) in Caucasian whortleberry was determined by Folin-Ciocalteu reagent, using Gallic acid as the standard $\left(\mathrm{R}^{2}=\right.$ 0.99). Folin-Ciocalteu's reagent was prepared with distilled water $(1: 10 \mathrm{v} / \mathrm{v}) .1 .0 \mathrm{ml}$ of extract, $5.0 \mathrm{ml}$ of Folin-Ciocalteu's reagent and $4.0 \mathrm{ml}$ $\mathrm{Na}_{2} \mathrm{CO}_{3}(\% 7.5)$ were mixed in the tubes. The mixtures were kept in a dark room for 1 hour. The absorbance was measured at $765 \mathrm{~nm}$ using a spectrophotometer (Lambda35, Perkin Elmer, USA) (Slinkard and Singleton, 1977). The total phenolic content was determined from the calibration curve and expressed in $\mathrm{mg}$ of Gallic acid equivalents/L. All of the experiments and analysis were performed in duplicates.

\section{Determination of colour values}

The colour values of the extracts were determined by a reader (Konica Minolta, C-400, Japan) that was equipped with a cup that holds the liquid samples. The colour meter was calibrated against a standard calibration plate of a white surface. The display was set to CIE L* a* $\mathrm{b}^{*}$ colour coordinates. Three readings per sample were recorded and the average values of colour parameters with standard deviation values were reported.

\section{Determination of dielectric properties}

Dielectric properties of samples were measured with an Agilent 85070E open-ended coaxial probe connected to an Agilent E8362B Vector Network Analyzer (Agilent Technologies ES061B ENA Series Network Analyzer, ABD) at room temperature. The network analyzer was calibrated with air, short block and distilled water at $25{ }^{\circ} \mathrm{C}$ (Sipahioglu and Barringer, 2003). All measurements were done in duplicates.

\section{Statistical analysis}

All of the statistical analysis and the response surface regression were performed using Minitab 16.0 software (Minitab, State College, PA). The models were used to plot contour lines. The significant difference between independent variables $(P \leq 0.05)$ was determined by Analysis of Variance. All of the experiments and analysis were performed in duplicates.

The experimental data were fit the following second order polynomial equation (Eq. 1) for each response variable (Gao et al., 2008). 
$\mathrm{Y}=\mathrm{b}_{0}+\mathrm{b}_{1} \mathrm{X}_{1}+\mathrm{b}_{2} \mathrm{X}_{2}+\mathrm{b}_{3} \mathrm{X}_{3}+\mathrm{b}_{4} \mathrm{X}_{1}^{2}+\mathrm{b}_{5} \mathrm{X}_{2}^{2}+\mathrm{b}_{6} \mathrm{X}_{3}^{2}+\mathrm{b}_{7} \mathrm{X}_{1} \mathrm{X}_{2}+\mathrm{b}_{8} \mathrm{X}_{1} \mathrm{X}_{3}+\mathrm{b}_{9} \mathrm{X}_{2} \mathrm{X}_{3}$

Where $b_{i}, Y$ and $X_{i}$ represent the coefficients, dependent and independent variables, respectively.

Process parameters, namely, microwave power $\left(\mathrm{X}_{1}, \mathrm{~W}\right)$, extraction time $\left(\mathrm{X}_{2}, \mathrm{~min}\right)$ and solid concentration $\left(\mathrm{X}_{3}, \%\right)$ were optimized by applying multiple optimization by using response optimizer in Minitab release 16 software (Table 1). Box-Behnken design was used for optimization. TPC, $\mathrm{L}^{*}, \mathrm{a}^{*}$ and $\mathrm{b}^{*}$ values were selected as the dependent variables.

Table 1. Experimental design including coded and uncoded independent variables

\begin{tabular}{|c|c|c|c|c|c|}
\hline \multicolumn{2}{|c|}{$X_{1}(\mathrm{~W})$} & \multicolumn{2}{|c|}{$X_{2}(\min )$} & \multicolumn{2}{|c|}{$X_{3}(\%)$} \\
\hline Coded & Uncoded & Coded & Uncoded & Coded & Uncoded \\
\hline 1 & 450 & 0 & 3 & 1 & 15 \\
\hline 0 & 360 & 0 & 3 & 0 & 10 \\
\hline 0 & 360 & 1 & 3.5 & 1 & 15 \\
\hline 0 & 360 & 1 & 3.5 & -1 & 5 \\
\hline-1 & 270 & -1 & 2.5 & 0 & 10 \\
\hline-1 & 270 & 1 & 3.5 & 0 & 10 \\
\hline 1 & 450 & 0 & 3 & 1 & 15 \\
\hline 0 & 360 & -1 & 2.5 & -1 & 5 \\
\hline 0 & 360 & -1 & 2.5 & -1 & 5 \\
\hline-1 & 270 & -1 & 2.5 & 0 & 10 \\
\hline 0 & 360 & -1 & 2.5 & 1 & 15 \\
\hline 0 & 360 & 0 & 3 & 0 & 10 \\
\hline 1 & 450 & 0 & 3 & -1 & 5 \\
\hline 0 & 360 & 1 & 3.5 & -1 & 5 \\
\hline 0 & 360 & 1 & 3.5 & 1 & 15 \\
\hline 0 & 360 & 0 & 3 & 0 & 10 \\
\hline 1 & 450 & 0 & 3 & -1 & 5 \\
\hline 1 & 450 & 1 & 3.5 & 0 & 10 \\
\hline-1 & 270 & 0 & 3 & 1 & 15 \\
\hline 1 & 450 & 1 & 3.5 & 0 & 10 \\
\hline-1 & 270 & 1 & 3.5 & 0 & 10 \\
\hline 0 & 360 & 0 & 3 & 0 & 10 \\
\hline 0 & 360 & -1 & 2.5 & 1 & 15 \\
\hline 0 & 360 & 0 & 3 & 0 & 10 \\
\hline 0 & 360 & 0 & 3 & 0 & 10 \\
\hline-1 & 270 & 0 & 3 & -1 & 5 \\
\hline 1 & 450 & -1 & 2.5 & 0 & 10 \\
\hline-1 & 270 & 0 & 3 & -1 & 5 \\
\hline-1 & 270 & 0 & 3 & 1 & 15 \\
\hline 1 & 450 & -1 & 2.5 & 0 & 10 \\
\hline
\end{tabular}

$*\left(\mathrm{X}_{1}\right.$, microwave power; $\mathrm{X}_{2}$, extraction time; $\mathrm{X}_{3}$, solid concentration $)$

\section{RESULTS AND DISCUSSIONS}

The effects of process variables such as microwave power $\left(\mathrm{X}_{1}\right)$, extraction time $\left(\mathrm{X}_{2}\right)$ and solid concentration $\left(\mathrm{X}_{3}\right)$ on total phenolic content and colour values $\left(\mathrm{L}^{*}, \mathrm{a}^{*}, \mathrm{~b}^{*}\right)$ were investigated by
RSM. The quadratic equations obtained by the regression analysis were shown in Table 2 . The equations had high regression coefficients $\left(\mathrm{R}^{2}>0.88\right)$ and the lack of fit values of the regression models were insignificant $(P>0.05)$. 
Table 2. Regression equations for Caucasian whortleberry extract at different extraction conditions

\begin{tabular}{|c|c|c|}
\hline Dependent variables & Model & $\mathrm{R}^{2}$ \\
\hline TPC & 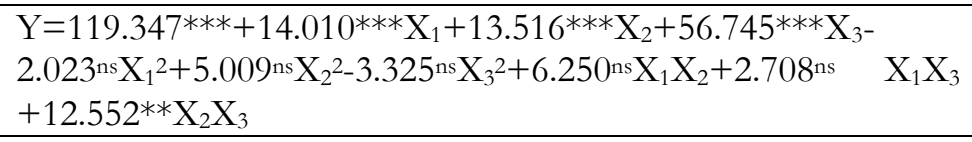 & 94.09 \\
\hline $\mathrm{L}^{*}$ value & $\begin{array}{l}\mathrm{Y}=15.0139^{* * *}-0.5960^{* *} \mathrm{X}_{1}-0.5875^{* *} \mathrm{X}_{2}-2.5710^{* * *} \mathrm{X}_{3}+ \\
0.1547^{\mathrm{ns}} \mathrm{X}_{1^{2}-0.1207^{\mathrm{ns}} \mathrm{X}_{2}^{2}+1.3639 * * *} \mathrm{X}_{3}^{2}-0.3671^{\mathrm{ns}} \mathrm{X}_{1} \mathrm{X}_{2}+ \\
0.5675^{*} \mathrm{X}_{1} \mathrm{X}_{3^{-}}-0.0387^{\mathrm{ns}} \mathrm{X}_{2} \mathrm{X}_{3}\end{array}$ & 89.76 \\
\hline$a^{*}$ value & 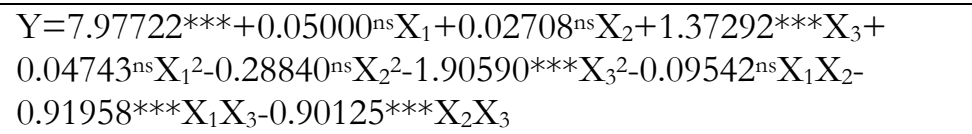 & 88.39 \\
\hline b* value & 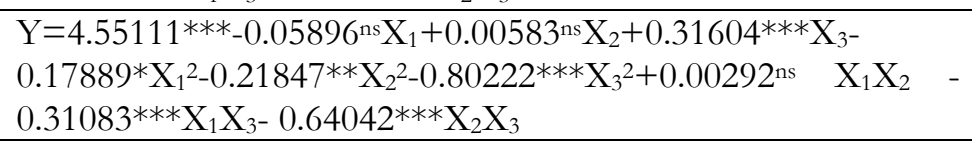 & 89.02 \\
\hline
\end{tabular}

The effects of extraction conditions on total phenolic content were visualized in Fig. 2 ( $a, b$ and c). The regression equations indicated that all of the independent variables had statistically significant impact on TPC (Table 2). There was a positive correlation between TPC and process variables, meaning that an increase in microwave power, extraction time and solid concentration have resulted in higher TPC. This result can also be seen in Fig. 2. It was observed that at constant solid concentration, increasing microwave power or extraction time increased the TPC (Fig. 2a). For example, the increase in MW power from 270 to $450 \mathrm{~W}$ (solid concentration: $10 \%$, extraction time: $2.5 \mathrm{~min}$ ) gave an average of $7 \%$ increase in TPC. In addition, the effect of MW power on TPC was more noticeable at longer extraction times. For instance, approximately $29 \%$ increase was observed in TPC when the MW power was increased from 270 to $450 \mathrm{~W}$ (solid concentration: $10 \%$, extraction time: $3.5 \mathrm{~min})$. It can also be reported that solid concentration was the most effective parameter on TPC among the independent variables studied (Fig. 2b). At low microwave power, increasing the solid concentration from $5 \%$ to $15 \%$ while keeping the extraction time constant gave a 3.2 fold rise in TPC. Moreover, it was found that at high solid concentrations the effect of extraction time on TPC was more pronounced (Fig. 2c). Similar results were also reported in literature. It was observed that TPC of blueberry leaves increased with increasing microwave power at constant extraction time (Routray and Orsat, 2014). It was stated that increasing the microware power level from $10 \%$ to $20 \%$ while keeping the extraction time constant (4 min) gave an approximately $20 \%$ rise in TPC. In a different study (Simic et al., 2016), microwave power and extraction time were also found to be statistically effective on the TPC of chokeberries.

Colour denotes the visual appearance of the product whereas pigments or colorants are the chemical compounds that impart the observed colour (Wrolstad et al., 2005). Anthocyanins, the most abundant group of polyphenols in blueberry, are responsible for the dark bluish red colour of the berries (Zheng et al., 2013; Routray and Orsat, 2014). The colour of the extract might change considerably depending on the phenolic groups extracted. The effects of extraction conditions on $\mathrm{L}^{*}, \mathrm{a}^{*}$ and $\mathrm{b}^{*}$ were visualized in Fig. 3, 4 and 5. Similar to TPC results, RSM findings had indicated that all of the independent variables had statistically significant impact on $L^{*}$ values (Table 2). A negative correlation was observed between $L^{*}$ value and independent variables, meaning that an increase in one of the process variables resulted in a lower $L^{*}$ value. This result can also be seen in Fig. 3 (a, b, c). This was an expected result, since more phenolic compounds were extracted at extreme extraction conditions, 
the colour of the extract will be darker which would lead to a lower $\mathrm{L}^{*}$ value.

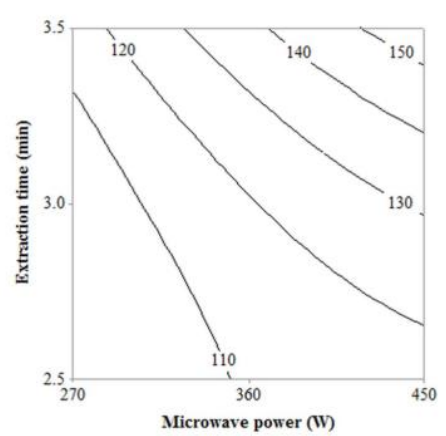

Fig. 2a. Variation of TPC of samples with microwave power and extraction time

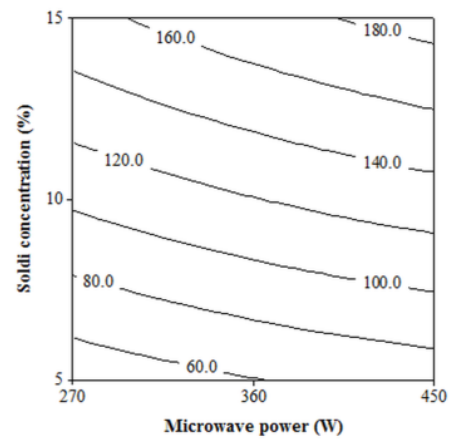

Fig. 2b. Variation of TPC of samples with microwave power and solid concentration

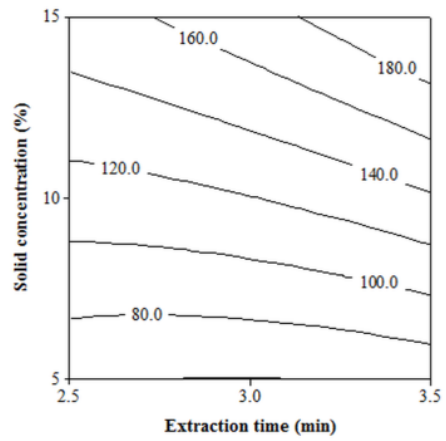

Fig. 2c. Variation of TPC of samples with extraction time and solid concentration

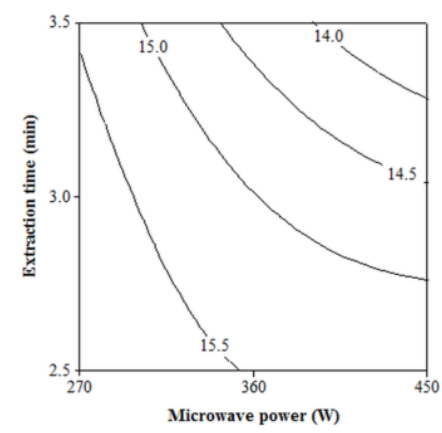

Fig. 3a. Variation of $\mathrm{L}^{*}$ values of the samples with microwave power and extraction time

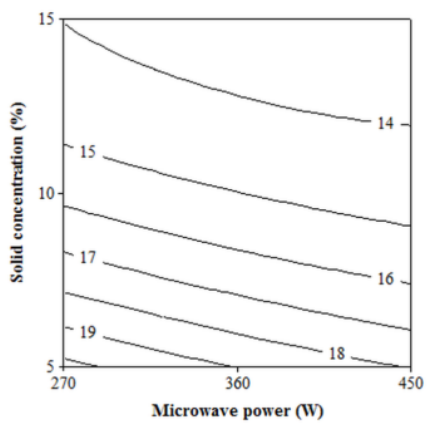

Fig. 3b. Variation of $L^{*}$ values of the samples with microwave power and solid concentration

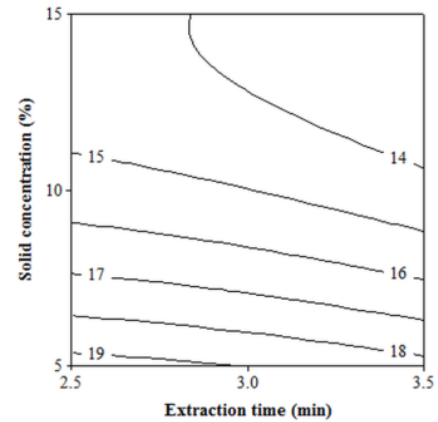

Fig. 3c. Variation of $L^{*}$ values of the samples with extraction time and solid concentration

Positive $\mathrm{a}^{*}$ and $\mathrm{b}^{*}$ values indicate the red and yellow colours in the extracts. It was found that only solid concentration was significantly effective on these colour values (Table 2). As the solid concentration increased, $\mathrm{a}^{*}$ and $\mathrm{b}^{*}$ values have also increased. At low microwave power, increasing solid concentration gave the highest $\mathrm{a}^{*}$ and $b^{*}$ values (Fig. 4 and 5). On the other hand, 
at high microwave powers, $a^{*}$ and $b^{*}$ values first increased with an increase in solid concentration, but then started to decline. This may indicate that at severe extraction conditions some of the pigments in the extract are being destructed.

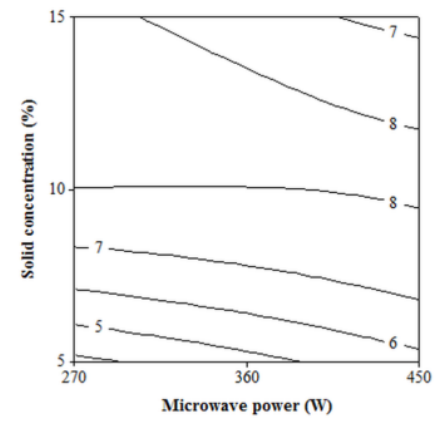

Fig. 4. Variation of $\mathrm{a}^{*}$ values of the samples with microwave power and solid concentration

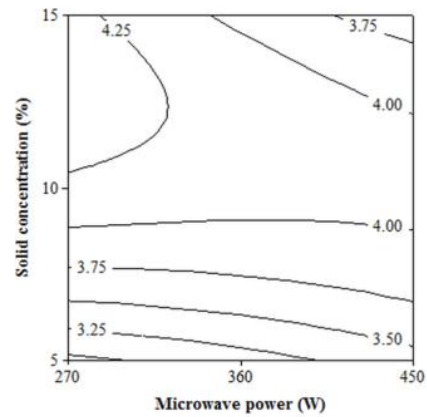

Fig. 5. Variation of $b^{*}$ values of the samples with microwave power and solid concentration

The correlations between TPC and the colour parameters were also investigated in this study (Fig. 6). It was observed that $\mathrm{L}^{*}$ and $\mathrm{a}^{*}$ values of the extracts were highly correlated with TPC by a second-order polynomial $\left(\mathrm{R}^{2}=0.95\right.$ and 0.91 , respectively) as shown on the graph. Lower $\mathrm{L}^{*}$ values corresponded to higher TPC. In contrast, first an increase was observed in $\mathrm{a}^{*}$ until a certain value is reached, at which point further increase in TPC resulted in a lower $\mathrm{a}^{*}$ value. This finding may signify that even though some phenolic compounds are continued to be extracted, other phenolic compounds (such as anthocyanin) are being destroyed at severe conditions. This is consistent with the results stated earlier in our study (Fig. 3). Moreover, no correlation was observed between $b^{*}$ values and the TPC. These results were in agreement with a study done by Yang and Zhai (2010), who have found a negative correlation between $\mathrm{L}^{*}$ and total anthocyanin content of purple corn. Similar results have also been reported such that chromatic parameters can be a helpful means for comparison and quick assessment of phenolic content in grape seed extract (Krishnaswamy et al., 2013).

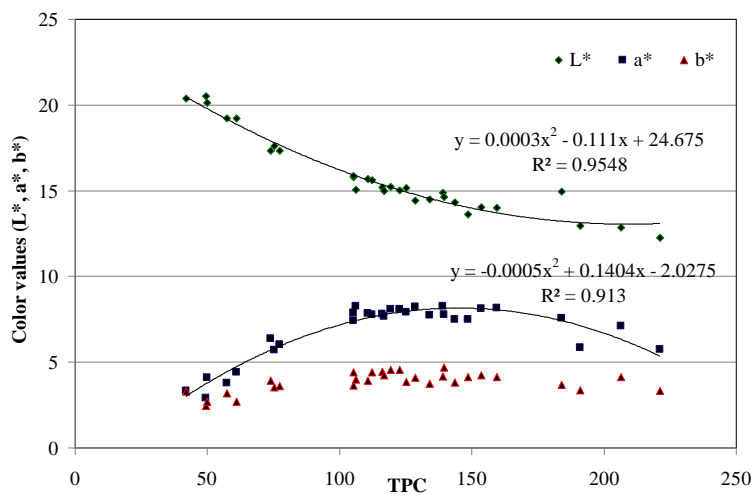

Fig. 6. Change of $\mathrm{L}^{*}, \mathrm{a}^{*}$ and $\mathrm{b}^{*}$ values with TPC

The dielectric constant and dielectric loss factor of the extracts were not affected by the independent variables. The average dielectric constant and dielectric loss factor of the samples were found as $76.25 \pm 1.54$ and $10.13 \pm 0.60$, respectively. The dielectric properties of the extracts were found to be close to those of pure water $\quad\left(\varepsilon^{\prime}=77.4\right.$ and $\left.\varepsilon^{\prime \prime}=13.0\right) \quad$ (Datta and Anantheswaran, 2001). This may be due to high water content of the samples after extraction.

The results of the RSM analysis revealed that the optimum process conditions were $450 \mathrm{~W}, 3.45$ min and $13.9 \%$ for microwave power, extraction time and solid concentration, respectively. The predicted TPC, $\mathrm{L}^{*}, \mathrm{a}^{*}$ and $\mathrm{b}^{*}$ values of extracts at optimum process conditions were $207 \mathrm{mg} / \mathrm{L}$, 12.86, 6.32 and 3.55 , respectively. To determine the validity of the predicted values, experiments were also performed at the optimal conditions which were found to be in close agreement, thus confirming the optimization process. As a control the Caucasian whortleberry samples were also extracted at optimum solid concentration $(13.9 \%)$ for $24 \mathrm{~h}$ at room temperature. TPC, $\mathrm{L}^{*} \mathrm{a}^{*}$ and $\mathrm{b}^{*}$ 
values of extract obtained after maceration was found as $156.5 \mathrm{mg} / \mathrm{L}, 22.71,11.77$ and 6.14, respectively. These findings indicated that microwave extraction not only reduced the extraction time significantly but also increased the TPC of the Caucasian whortleberry extracts by approximately $32 \%$. It can also be reported that the microwave assisted extraction samples were darker. This was an expected result, since more phenolic compounds were extracted by MAE. However, $a^{*}$ value of the extract obtained after maceration was higher than that of MAE. This finding may indicate that phenolic compounds which provides the red colour (anthocyanins) were much better extracted by maceration.

\section{CONCLUSION}

Total phenolic content, colour values and dielectric properties of Caucasian whortleberry extracts were investigated in this study. Response surface methodology was successfully applied for the optimization of the MAE conditions (microwave power, extraction time and solid concentration). A positive correlation was found between total phenolic contents and process variables. $\mathrm{L}^{*}$ and $\mathrm{a}^{*}$ values of the extracts were found to be highly correlated with total phenolic contents by a second-order polynomial. The independent variables did not have any influence on the dielectric constant and dielectric loss factors of the extracts. The total phenolic content of the extract obtained at the optimal condition was approximately $32 \%$ greater than that of the maceration method. The results also showed that microwave extraction decreased the extraction time significantly. Thus, MAE can be recommended as an alternative method to conventional extraction for the extraction of phenolic compounds from Caucasian whortleberry.

\section{ACKNOWLEDGEMENT}

The authors thank "Hopa Yaban Mersini" company for providing Caucasian whortleberry.

\section{REFERENCES}

Ardestani, S.B., Sahari, M.A., Barzegar, M. (2016). Effect of extraction and processing conditions on anthocyanins of barberry. J Food Process Pres, 40(6): 1407-1420.
Boukroufa, M., Boutekedjiret, C., Petigny, L., Rakotomanomana, N., Chemat, F. (2015). Biorefinery of orange peels waste: a new concept based on integrated green and solvent free extraction processes using ultrasound and microwave techniques to obtain essential oil, polyphenols and pectin. Ultrasonics Sonochemistry, 24: 72-79.

Chen, M., Zhao, Y., Yu, S. (2015). Optimisation of ultrasonic-assisted extraction of phenolic compounds, antioxidants, and anthocyanins from sugar beet molasses. Food Chem, 172: 543-550.

Dahmoune, F., Nayak, B., Moussi, K., Remini, H., Madani, K. (2015). Optimization of microwaveassisted extraction of polyphenols from Myrtus communis L. leaves. Food Chem, 166: 585-595.

Datta, A.K., Anantheswaran, R.C. (2001) Handbook of Microwave Technology and Applications. Marcel Dekker, Inc., NY, USA.

Gao, Z.J., Lin, H., Xiao, H.W. (2008). Airimpingement de-shelling of chestnuts (C. mollisima): process parameter optimization. Int $J$ Food Eng, 4(2): 15.

Gharekhani, M., Ghorbani, M., Rasoulnejad, N. (2012). Microwave-assisted extraction of phenolic and flavonoid compounds from Eucalyptus camaldulensis dehn leaves as compared with ultrasound-assisted extraction. Latin Am Appl Res, 42(3): 305-310.

Giovanelli, G., Buratti, S. (2009). Comparison of polyphenolic composition and antioxidant activity of wild Italian blueberries and some cultivated varieties. Food Chem, 112: 903-908.

Ivanovic, J., Tadic, V., Dimitrijevic, S., Stamenic, M., Petrovic, S., Zizovic, I. (2014). Antioxidant properties of the anthocyanin-containing ultrasonic extract from blackberry cultivar “Čačanska Bestrna”. Ind Crops Prod, 53: 274-281.

Jacquemart, A.L. (1996). Biological Flora of the British Isles: Vaccinium uliginosum L. J Ecol, 84: 771-785.

Jokic, S., Cvjetko, M., Bozic, D., Fabek, S., Toth, N., Vorkapic-Furac, J., Redovnikovic, I.R. (2012). Optimisation of microwave-assisted extraction of phenolic compounds from broccoli and its 
antioxidant activity. Int J Food Sci Technol, 47(12): 2613-2619.

Karabegovic, I.T., Stojicevic, S.S., Velickovic, D.T., Todorovic, Z.B., Nikolic, N.C., Lazic, M.L. (2014). The effect of different extraction techniques on the composition and antioxidant activity of cherry laurel (Prunus laurocerasus) leaf and fruit extracts. Ind Crops Prod, 54: 142-148.

Kislik, V.S. (2012). Engineering development of solvent extraction processes, solvent extraction. Elsevier, Amsterdam, Netherland, pp. 157-184.

Krishnaswamy, K., Orsat, V., Gariepy, Y., Thangavel, K. (2013). Optimization of microwave-assisted extraction of phenolic antioxidants from grape seeds (Vitis vinifera). Food Bioprocess Technol, 6(2): 441-455.

Prior, R.L., Cao, G., Martin, A., Sofic, E., Mcewen, J., O'brien, C., Lischner, N., Ehlenfeldt, M., Kalt, W., Krewer, G., Mainland, C.M. (1998). Antioxidant capacity as influenced by total phenolic and anthocyanin content, maturity, and variety of $V$ accinium species. J Agric Food Chem, 46: 2686-2693.

Routray, W., Orsat, V. (2014). MAE of phenolic compounds from blueberry leaves and comparison with other extraction methods. Ind Crops Prod, 58: 36-45.

Routray, W., Orsat, V., Gariepy, Y. (2014). Effect of different drying methods on the microwave extraction of phenolic components and antioxidant activity of high bush blueberry leaves. Drying Technol, 32: 1888-1904.

Setyaningsih, W., Saputro, I.E., Palma, M., Barroso, C.G. (2015). Optimisation and validation of the microwave-assisted extraction of phenolic compounds from rice grains. Food Chem, 169: 141-149.

Simic, V.M., Rajkovic, K.M., Stojicevic, S.S., Velickovic, D.T., Nikolic, N.C., Lazic, M.L., Karabegovic, I.T. (2016). Optimization of microwave-assisted extraction of total polyphenolic compounds from chokeberries by response surface methodology and artificial neural network. Sep Purif Technol, 160: 89-97.

Sipahioglu, O., Barringer, S.A. (2003). Dielectric properties of vegetables and fruits as a function of temperature, ash and moisture content. J Food Sci, 68: 234-239.

Slinkard, K., Singleton, V.L. (1977). Total phenol analysis: Automation and comparison with manual methods. Am J Enol Vitic, 28: 49-55.

Sookjitsumran, W., Devahastin, S., Mujumdar, A.S., Chiewchan, N. (2016). Comparative evaluation of microwave-assisted extraction and preheated solvent extraction of bioactive compounds from a plant material: a case study with cabbages. Int J Food Sci Technol, 51(11): 24402449 .

Wrolstad, R.E., Durst, R.W., Lee, J. (2005). Tracking color and pigment changes in anthocyanin products. Trends Food Sci Technol, 16: 423-428.

Xu, D.P., Zhou, Y., Zheng, J., Li, S., Li, A.N., Li, H.B. 2016. Optimization of Ultrasound-Assisted Extraction of Natural Antioxidants from the Flower of Jatropha integerrima by Response Surface Methodology. Molecules, 21(18), 1-12.

Yang, Z., Zhai, W. (2010). Optimization of microwave-assisted extraction of anthocyanins from purple corn (Zea mays L.) cob and identification with HPLC-MS. Innov Food Sci Emerg Technol, 11: 470-476.

Zheng, X., Zu, X., Liu, C., Sun, Y., Lin, Z., Liu, H. (2013). Extraction characteristics and optimal parameters of anthocyanin from blueberry powder under microwave-assisted extraction conditions. Sep Purif Technol, 104: 17-25.

Zhou, Y., Zhao, X., Huang, H. (2015). Effects of pulsed electric fields on anthocyanin extraction yield of blueberry processing by-products. J Food Process Pres, 39: 1898-1904. 